\title{
Alleviating the Adverse Effect of Salinity on Maize by the Ameliorative Effect of Salicylic Acid
}

\author{
O.M. Ibrahim ${ }^{\#}$, A.A. Gaafar*, B. A. Bakry ${ }^{* *}$, M.F. El \\ Kramany $^{* *}$ \\ Plant Production Department, Arid Lands Cultivation \\ Research Institute, City of Scientific Research and \\ Technological Applications (SRTA-City), New Borg El-Arab, \\ Alexandria 21934; 'Soil Salinity and Alkalinity Laboratory, \\ Soil, Water \& Environment Research Institute, Agricultural \\ Research Center and ${ }^{* *}$ Field Crops Res. Dept., National \\ Research Centre, P.O.12622, Cairo, Egypt.
}

$\mathbf{T}$ WO EXPERIMENTS in cemented plots were conducted during 2012 and 2013 summer seasons at Soil Salinity and Alkalinity Lab., Alexandria, Egypt, to study the effect of three levels of irrigation water salinity $(0.5,2.75$, $\left.5.5 \mathrm{dSm}^{-1}\right)$ and spraying leaves with salicylic acid $(0,100,200 \mathrm{ppm})$ on growth, grain yield, and the components of maize grain yield. Split plot with four replicates was the experimental design. The results revealed that at midseason, irrigation with saline water significantly decreased plant height $(\mathrm{cm})$, fresh weight of plant $(\mathrm{g})$, and dry weight of plant $(\mathrm{g})$. However, number of leaves/plant, leaves area/plant $\left(\mathrm{m}^{2}\right)$ and leaf area index were not significantly affected. Also, at mid-season foliar spraying with salicylic acid significantly increased fresh weight of plant $(\mathrm{g})$ and dry weight of plant $(\mathrm{g})$. However, plant height $(\mathrm{cm})$, number of leaves/plant, leaves area/plant $\left(\mathrm{m}^{2}\right)$, and leaf area index were not significantly affected. At end-season irrigation with saline water significantly decreased ear height $(\mathrm{cm})$, ear weight $(\mathrm{g})$, number of grains/row, 100 kernel weight (g), grain yield (g/plot), biological yield (g/plot), straw yield (g/plot) and harvest index while number of rows/ear had not been affected significantly. Also, at end-season foliar application of salicylic acid significantly increased all the studied parameters except for ear height $(\mathrm{cm})$, number of rows/ear and harvest index. The interaction between salinity and salicylic acid was not significant for all the studied parameters except for grain yield meaning that every factor is acting independently from each other. In conclusion, salicylic acid could be used as an antioxidants or potential growth regulator to improve maize growth and grain yield under salinity conditions.

Keywords: Irrigation water, Salinity, Salicylic acid, Maize, Growth regulators.

Abiotic stress like salinity is known to reduce major physiological processes like photosynthesis. Khodary (2004) found a significant reduction in photosynthesis in maize due to the salinity of irrigation water. However, the degree of reduction caused by salt stress depends on leaf area, pigments, stomatal conductance (Dubey, 2005). 
Salinity stress lead to the formation of reactive oxygen species (ROS) such as hydrogen peroxide $\left(\mathrm{H}_{2} \mathrm{O}_{2}\right)$ which in turn lead to the damage of chloroplasts. Plants produced many types of antioxidant compounds like salicylic acid to get rid of (ROS). Salt tolerance has been found to be associated with the antioxidant system (Mittler, 2002). So, it was suggested that salt tolerance may be enhanced by foliar application of antioxidant like salicylic acid. The phenolic compounds like salicylic acid are produced naturally in plants and play a role as growth regulator (Arberg, 1981). Spraying of salicylic acid may affect some physiologically major processes such as photosynthesis (El-Tayeb, 2005; Khan et al., 2003 and Khodary, 2004). Crop productivity is mainly affected by photosynthesis which takes place in green leaves where chlorophyll content is the molecule that photosynthesis depends on it. Shutting et al. (1997) found that higher grain yield produced by maize cultivars was maintained by high content of photosynthesis, also, these cultivars had higher transpiration rate, stomatal conductance and leaf area. Thus, the biological and grain yield can be improved by enhancing the rate of photosynthesis. Lopez (1989) stated that an increase in wheat grain yield was achieved by foliar application of salicylic acid. Rui et al. (1986) reported that closing of stomata was happened by abscisic acid which induced by abiotic stresses such as drought and salinity was reversed by salicylic acid.

The objective of the current study was to investigate the effect of salicylic acid as a protectant to ameliorate the adverse influence of irrigation with saline water on maize and consequently increase its salt tolerance.

\section{Materials and Methods}

Two experiments in cemented plots were conducted during the summer seasons of 2012 to 2013, Soil Salinity and Alkalinity Laboratory, Alexandria, Egypt, to investigate the effect of three levels of salicylic acid $(0,100,200 \mathrm{ppm})$ and irrigation water salinity $\left(0.5,2.75,5.5 \mathrm{dSm}^{-1}\right)$ on growth, grain yield and the components of maize grain yield cultivar (Gemmeiza 12). The soil was analyzed according to Chapman \& Pratt (1978) before sowing and had the following mechanical and chemical characters.

TABLE 1. Physical and chemical analyses of soil before sowing and analysis of tap water and well water.

\begin{tabular}{|c|c|c|c|c|c|c|c|c|}
\hline \multicolumn{9}{|c|}{ Soil } \\
\hline $\begin{array}{c}\text { Sand } \\
\%\end{array}$ & $\begin{array}{c}\text { Silt } \\
\%\end{array}$ & $\begin{array}{c}\text { Clay } \\
\%\end{array}$ & Soil texture & \multicolumn{2}{|c|}{$\begin{array}{c}\text { E.C. } \\
\text { dSm }^{-1}\end{array}$} & pH & $\begin{array}{c}\text { S.P. } \\
\%\end{array}$ & SAR \\
\hline 74.0 & 10.4 & 15.6 & Sandy loam & \multicolumn{2}{|c|}{1.82} & 7.53 & 43.33 & 1.49 \\
\hline \multicolumn{9}{|c|}{ Tap water } \\
\hline $\mathrm{pH}$ & $\begin{array}{c}\text { E.C. } \\
\text { dSm }^{-1}\end{array}$ & $\mathrm{Ca}^{2+}$ & $\mathrm{Mg}^{2+}$ & $\mathrm{K}^{+}$ & $\mathrm{Na}^{+}$ & $\mathrm{HCO}_{3}^{-}$ & $\mathrm{Cl}^{-}$ & $\mathrm{SO}_{4}{ }^{2-}$ \\
\hline 7.6 & 0.62 & 2.2 & 1.73 & 0.18 & 2.75 & 3.55 & 2.11 & 1.2 \\
\hline \multicolumn{9}{|c|}{ Well water } \\
\hline 7.8 & 5.44 & 1.8 & 2.4 & 3.9 & 48.0 & 2.9 & 32.0 & 13.9 \\
\hline
\end{tabular}

Egypt. J. Agron.38, No.3 (2016) 
The design of the experiment was split plot with four replicates where irrigation water salinity levels were located in the main plots which distributed in RCBD, while salicylic acid levels were located in the subplots, the experimental unit was a cemented plot with a dimension of $150 \mathrm{~cm}$ in long and $75 \mathrm{~cm}$ in wide with an area of $1.125 \mathrm{~m}^{2}$. Every cemented plot contains four rows, the grains were sown in May and before sowing the cemented plots were prepared by adding calcium superphosphate $15.5 \% \mathrm{P}_{2} \mathrm{O}_{5}$ at a rate of $100 \mathrm{~kg} / \mathrm{faddan}(\mathrm{Hectare}=$ 2.38 faddan) and potassium sulfate $48 \% \mathrm{~K}_{2} \mathrm{O}$ at a rate of $50 \mathrm{~kg} /$ faddan, the nitrogen fertilizer was added at the rate of $125 \mathrm{~kg} \mathrm{~N} /$ faddan of ammonium sulfate $20.5 \% \mathrm{~N}$ at three doses, the first at sowing, the second at the first irrigation, and the third at the second irrigation. Irrigation with saline water was adopted after one month of sowing. Salicylic acid was initially dissolved in a few drops of Dimethyl sulfoxide and the final volume was reached by adding distilled water, then the $\mathrm{pH}$ was adjusted at 6-7 with $\mathrm{NaOH}(1.0 \mathrm{~N})$. A constant volume of solutions were sprayed twice on the leaves in the early morning when the plants had their fourth leaf and two weeks later.

At mid-season a sample of one plant from each plot was taken to measure the following parameters:

1. Plant height $(\mathrm{cm})$

2. Number of leaves/plant

3. Leaves area/plant $\left(\mathrm{m}^{2} /\right.$ plant $)$

4. Leaf area index $\left(\mathrm{m}^{2} / \mathrm{m}^{2}\right)$

5. Plant fresh weight $(\mathrm{g})$

6. Plant dry weight $(\mathrm{g})$

At the end of the experiment the following characters were measured:

1- Ear height $(\mathrm{cm})$

2- Ear weight (g)

3- Number of rows/ear

4- Number of grains/row

5- 100 kernel weight $(\mathrm{g})$

6- Grain yield (g/plot)

7- Biological yield (g/plot)

8- Straw yield (g/plot)

9- Harvest index $(\%)$

Since the trends in both seasons were similar, the test of homogeneity was carried out according to Prattle's test and the combined analysis of the data was applied according to Snedecor \& Cochran (1982). After harvest, salinity of soil drain of 2.75 and $5.5 \mathrm{dSm}^{-1}$ treatments were 3.5 to 4 and 6.5 to $8 \mathrm{dSm}^{-1}$, respectively, so, plots were subjected to leaching by adding excess amounts of tap water until EC of soil drain was under $2 \mathrm{dSm}^{-1}$. 


\section{Results and Discussions}

The adverse effect of salinity at mid-season

Irrigation with saline water resulted in a significantly decrease in plant height, fresh weight of plant, dry weight of plant (Table 2) where irrigation with 2.75 and $5.5 \mathrm{dSm}^{-1}$ lead to a decrease of 6 and $12 \%$ in plant height, respectively. Also, a reductions of 7 and $15 \%$ in fresh weight of plant were observed due to the irrigation with 2.75 and $5.5 \mathrm{dSm}^{-1}$, respectively, while in dry weight of plant the reduction were 12 and $15 \%$. However, saline water had no significant effect on number of leaves/plant, leaves area/plant and LAI.

TABLE 2. Effect of salinity and salicylic acid on maize growth at mid-season (combined analysis of 2012 and 2013 seasons).

\begin{tabular}{|c|c|c|c|c|c|c|}
\hline Treatments & $\begin{array}{c}\text { Plant } \\
\text { height } \\
(\mathrm{cm})\end{array}$ & $\begin{array}{c}\text { No. of } \\
\text { leaves/ } \\
\text { plant }\end{array}$ & $\begin{array}{c}\text { Leaves } \\
\text { area/ } \\
\text { Plant,m² }\end{array}$ & LAI & $\begin{array}{c}\text { Fresh } \\
\text { weight/ } \\
\text { plant }(g)\end{array}$ & $\begin{array}{c}\text { Dry } \\
\text { weight/ } \\
\text { plant(g) }\end{array}$ \\
\hline \multicolumn{7}{|c|}{ Water salinity } \\
\hline Control & $186.3 \mathrm{a}$ & $14.5 \mathrm{a}$ & $0.74 \mathrm{a}$ & $5.3 \mathrm{a}$ & $521.2 \mathrm{a}$ & $86.4 \mathrm{a}$ \\
\hline $2.75 \mathrm{dSm}^{-1}$ & $174.6 \mathrm{~b}$ & $14.5 \mathrm{a}$ & $0.71 \mathrm{a}$ & $5.0 \mathrm{a}$ & $481.7 \mathrm{ab}$ & $75.9 \mathrm{ab}$ \\
\hline $5.5 \mathrm{dSm}^{-1}$ & $164.1 \mathrm{~b}$ & $14.2 \mathrm{a}$ & $0.71 \mathrm{a}$ & $5.0 \mathrm{a}$ & $442.1 \mathrm{~b}$ & $73.7 \mathrm{~b}$ \\
\hline \multicolumn{7}{|c|}{ Salicylic acid } \\
\hline Control & $168.3 \mathrm{a}$ & $14.3 \mathrm{a}$ & $0.71 \mathrm{a}$ & $5.0 \mathrm{a}$ & $437.9 \mathrm{~b}$ & $69.6 \mathrm{~b}$ \\
\hline $100 \mathrm{ppm}$ & $181.8 \mathrm{a}$ & $14.2 \mathrm{a}$ & $0.72 \mathrm{a}$ & $5.1 \mathrm{a}$ & $499.2 \mathrm{ab}$ & $82.3 \mathrm{a}$ \\
\hline $200 \mathrm{ppm}$ & $174.8 \mathrm{a}$ & $14.7 \mathrm{a}$ & $0.72 \mathrm{a}$ & $5.2 \mathrm{a}$ & $507.9 \mathrm{a}$ & $84.2 \mathrm{a}$ \\
\hline
\end{tabular}

These results are in harmony with those obtained by Khodary (2004), Hussein et al.(2007) and Singh et al.(2015), they recorded a significant reduction in plant height, fresh weight of plant, dry weight of plant, and leaves area/plant due to irrigation water salinity. Also, Desoky \& Merwad (2015) reported similar results for wheat.

The adverse effect of salinity at end-season

Data in Table 3 revealed that saline irrigation water significantly decreased ear height, ear weight, number of grains/row, 100 kernel weight, grain yield, biological yield, straw yield, and harvest index. However, number of rows/ear was not significantly affected by salinity. When irrigating with 2.75 and 5.5 $\mathrm{dSm}^{-1}$, respectively, the reduction in ear height were 9.2 and $9.6 \%$, the reduction in ear weight were 43 and $56 \%$, the decrease in number of grains/row were 32.6 and $38.4 \%$, the decrease in 100 kernel weight were 15 and $22.3 \%$, the decrease in grain yield were 36.6 and $58.1 \%$, the decrease in biological yield were 17.7 and $27.8 \%$, the decrease in straw yield were 14.6 and $22.8 \%$ and finally the decrease in harvest index were 21.4 and $42.9 \%$. The results of the current study are in general accordance with those obtained by Khodary (2004) and Hussein et al. (2007) where they recorded a significant reduction in maize growth due to irrigation water salinity, however, they did not reach to end-season.

Egypt. J. Agron.38, No.3 (2016) 


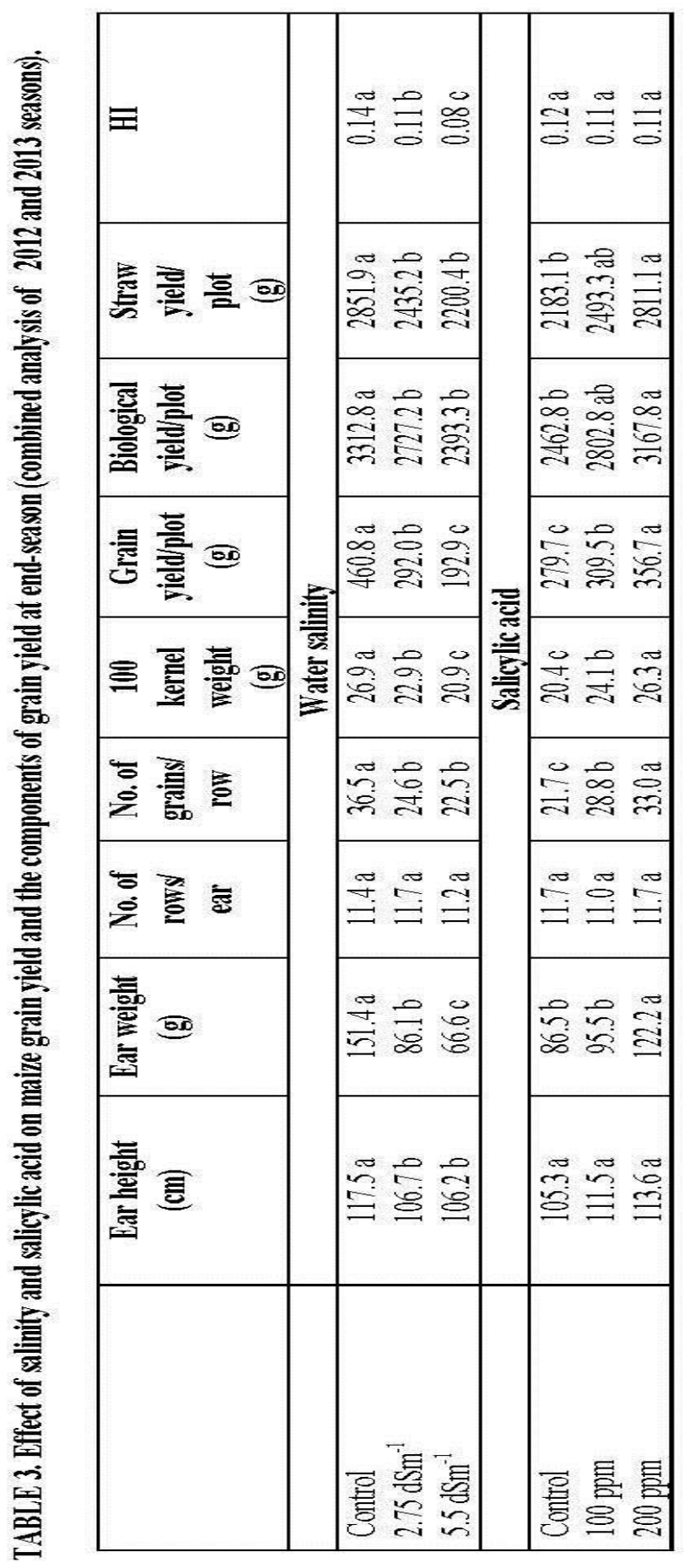

Egypt. J. Agron .38, No. 3 (2016) 
The ameliorative effect of salicylic acid at mid-season

Table 2 showed that foliar application of salicylic acid had no significant effect on plant height, number of leaves/plant, leaves area/plant, and leaf area index. However, both fresh weight and dry weight of plant were significantly increased by spraying salicylic acid where the concentrations of 100 and $200 \mathrm{ppm}$ caused an increase of 14 and $16 \%$ in fresh weight of plant, respectively and an increase of 18 and $21 \%$ in dry weight of plant, respectively with no significant difference between the levels of 100 and 200 ppm of salicylic acid.

These results are in accordance with those obtained by Hussein et al. (2007) who stated that salicylic acid significantly increased dry weight of plant by $46 \%$ when sprayed with $200 \mathrm{ppm}$ compared to control treatment, also, they stated a non-significant increase in area of leaves. However, a contradiction with the same author was found regarding plant height and number of leaves where they stated a significant increase in those parameters.

Also, Khodary ( 20040 and Singh et al. (2015) recorded a significant increase in plant height, fresh weight of plant, dry weight of plant, leaves area/plant when plant were exposed to salicylic acid of $10^{-2} \mathrm{M}$ and $0.5 \mathrm{mM}$, respectively compared to control treatment. Also, Desoky \& Merwad (2015) stated similar results for wheat.

The ameliorative effect of salicylic acid at end-season

Table 3 illustrated that foliar application of salicylic acid had no significant effect on ear height, number of rows/ear, and harvest index. However, it had significantly increased ear weight, number of grains/row, 100 kernel weight, grain yield, biological yield, and straw yield where increasing the levels of salicylic acid from control to 100 and $200 \mathrm{ppm}$ resulted in an increase in ear weight of 10 and $41 \%$, number of grains/row increased by 32 and $52 \%, 100$ kernel weight increased by 18 and $29 \%$, grain yield increased by 10 and $27 \%$, biological yield increased by 14 and $28 \%$, straw yield increased by 11 and $22 \%$, respectively.

The results of the current experiment agree with Amin et al. (2008) who recorded a significant increase in grain yield of wheat of 43 and $33 \%$ when the plant were sprayed with 100 and 200 ppm of salicylic acid.

The effect of interaction between salinity and salicylic acid

Figure 1 showed that exogenous application of salicylic acid caused a significant increase in grain yield under all treatments of irrigation water salinity meaning that salicylic acid can play an important role as antioxidants to increase salinity tolerance of salt sensitive plants like maize. 


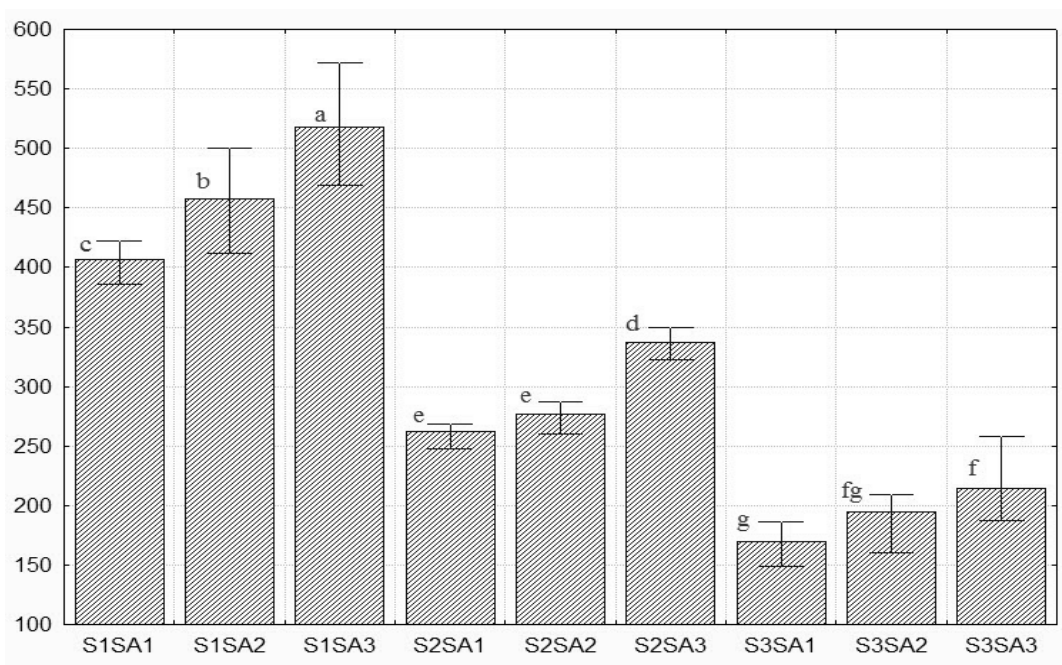

Fig. 1. Means of grain yield (g/plot) as affected by the interaction between salinity (S) and salicylic acid (SA).

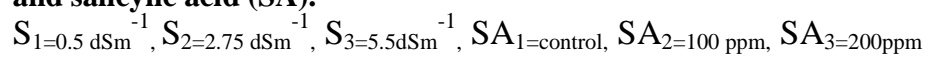

\section{Conclusion}

The ameliorative effects of salicylic acid on maize growth as well as grain yield and the components of grain yield were achieved at the level of $200 \mathrm{ppm}$ which suggests that salicylic acid could be used as an antioxidants or regulator of growth to improve maize growth and grain yield under salinity conditions.

\section{References}

Amin, A.A., Rashad, El-Sh. M. and Gharib, Fatma A.E. (2008) Changes in morphological, physiological and reproductive characters of wheat plants as affected by foliar application with salicylic acid and ascorbic acid. Australian Journal of Basic and Applied Sciences, 2(2), 252-261.

Arberg, B. (1981) Plant growth regulators XLI. Mono substituted benzoic acid. Swed. J. Agric. Res. 11, 93-105.

Chapman, H. O. and Pratt, P. E. (1978) "Methods of Analysis for Soil, Plants and Waters". Univ. Calif. Div. Agic. Sci.

Desoky, E. M. and Merwad, A. M. (2015) Improving the salinity tolerance in wheat plants using salicylic and ascorbic acids. Journal of Agricultural Science, 7(10), 203217.

Dubey, R.S. (2005) Photosynthesis in plants under stressful conditions. In:"Photosynthesis Handbooks". $2^{\text {nd }}$ ed. M. Pessarakli (Ed.), p. 717-718. C.R.C. Press, New York.

Egypt. J. Agron .38, No. 3 (2016) 
El-Tayeb, M.A. (2005) Response of barley grain to the interactive effect of salinity and salicylic acid. Plant Growth Regul. 45, 215-24.

Hussein, M.M., Balbaa L.K. and Gaballah, M.S. (2007) Salicylic acid and salinity effects on growth of maize plants. Research Journal of Agriculture and Biological Sciences, 3(4), 321-328.

Khan, W., Prithiviraj, B. and Smith, D.L. (2003) Photosynthetic response of corn and soybean to foliar application of salicylates. J. Plant Physiol. 160, 485-92.

Khodary, S.E.A. (2004) Effect of salicylic acid on growth, photosynthesis and carbohydrate metabolism in salt stressed maize plants. Int. J. Agric. Biol. 6, 5-8.

Lopez, T.R. (1989) Evaluacion de acido salicilico para incrementar numero de granos por espiga yrendimiento entrigo Triticum durum var. Altar c-84, valledel Yaqui, son, tesis de licenciatura. Instituto Tecnologico de Sonora.

Mittler, R. (2002) Oxidative stress, antioxidants and stress tolerance. Trends Plant Sci. 7,. 405- 410 .

Rui, V.K., Sharma, S.S. and Sharma, S. (1986) Reversal of ABA-induced stomatal closure by phenolic compounds. J. Exp. Bot. 37,129-34.

Shutting, D., Rongqi, G., Changltao, H., Qunying, W. and Koogjun, W. (1997) Study of canopy photosynthesis properties and high yield potential after anthesis in maize. Acta Agron. Sin. 23(3), 318-25.

Singh, P.K., Shahi, S.K. and Singh, A.P. (2015) Indian Journal of Plant Sciences. 4 (1), 69-77.

Snedecor, G. W. and Cochran W.G. (1982) "Statistical Methods" $7^{\text {th }}$ ed., Iowa State Press, Iowa, USA.

(Received 10/11/2016;

accepted 10/1/2017)

Egypt. J. Agron.38, No.3 (2016) 


\title{
تقليل التاثير السلبى للملوحة على الذرة بواسطة التاثير الايجابى لحمض السالسيليك
}

\author{
عمر مغاورى ابراهيم ، على عبد المجيد جعفر" ، بكرى احمد بكرى** و محمد

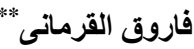 \\ قسم الانتاج النباتى - معهد بحوث زروانى زعة الاراضى القاحلة - مدينة الابحاث

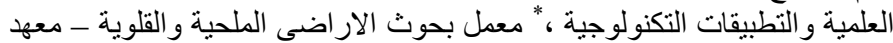

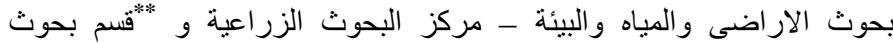 \\ المحاصيل الحقلية ـ المركز القومى للبحوث ـ القاهره - مصر.
}

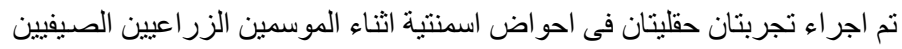

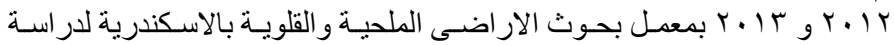

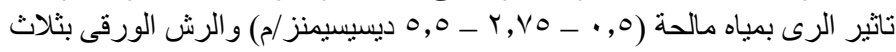

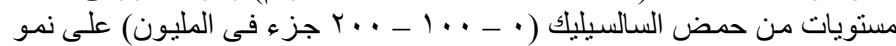

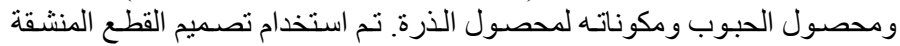

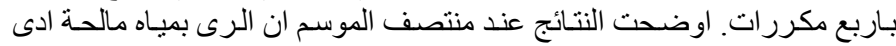

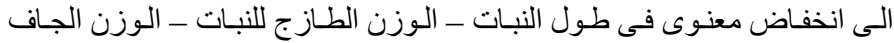

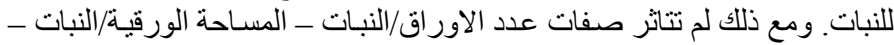

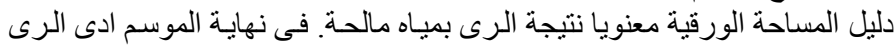

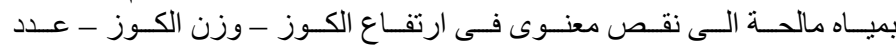

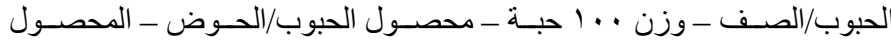

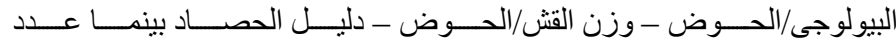

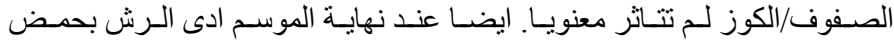

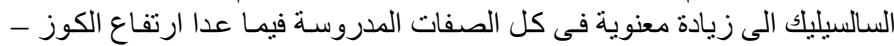

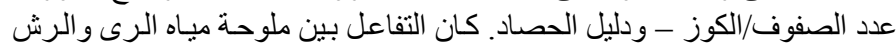

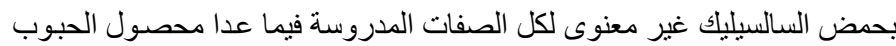

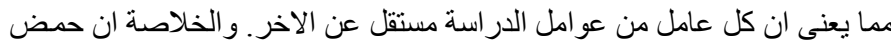

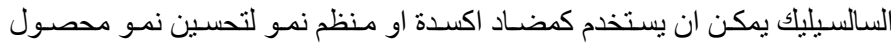
حبوب الذرة تحت ظروف الملوحة.
\end{abstract}

